\title{
カントレコーダによる白鋳鉄中のリンの定量*
}

\author{
岡 友美 ${ }^{* *}$. 根本 弘 ${ }^{* *}$. 倉田 栄**
}

（昭和 37 年 9 月 24 日受理）

\section{Quantometric Analysis of Phosphorus in White Cart Iron}

\author{
Tomomi OKA, Hiroshi NEMOTO and Sakae KURATA
}

(Kantô Special Steel Co., Ltd.)

For the purpose of establishing routine quantometric analysis of phosphorus in white cast iron, a study has been made on various conditions of analytical techniques with the following results.

(1) Excitation by a low voltage discharge (L: $360 \mu \mathrm{H}, \mathrm{C}: 30 \mu \mathrm{F}, \mathrm{R}: 50 \Omega$ ) gives satisfactory results.

(2) Good results with reproducibility of below $4 \%$ variation are obtained by 10 sec. of pre-spark time and $20 \mathrm{sec}$. of constant integration time, the internal standard method being not used.

(3) This procedure can be applied to the determination of phosphorus content in the range from $0.04 \%$ to $0.6 \%$.

(4) To raise the accuracy in this procedure, the following effects on the result should be taken into consideration:

a) Effect of metallurgical history of the sample.

b) Effect of cracks on the sample surface.

c) Effect of change in relative positions between exit slit and spectral lines by temperature variation.

\section{1. 緒言}

炭素, リン，イオウの諸元素は，従来から分光分析に よつて定量することが困難視されていたが，最近，P I

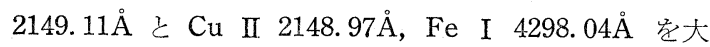
形回折格子分光器の 2 次スペクトルを用いて分離し, 光 電測光によつて分析する方法が見出されてからカントメ

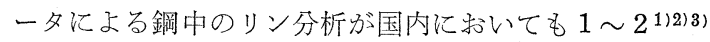
で実用化されている.しかし，鋳鉄中のリン分析注実用 化されているところがないようである.ごく最近は，真 空発光分光分析によつて鋼中のリンが4(5)6), 炭素, イオ ウおよび他の元素とともに定量されているが，鋳鉄につ いては検討されても国内では，実用化するところまでに

\footnotetext{
* 昭和36年11月10日, 日本分光学会講演会にて一部 学表

** 関東特殊製鋼株式会社（藤沢市辻堂1110）

1) 島津, 吉野, 佐野: 分光研究， 3, 20 (1955).

2) 河合, 浦野, 宮原：鉄々鋼， 10, 1081 (1960).

3）遠山：最新の分析化学, 第12集, 123 (1961).

4) 浜口：最新の分析化学, 第12集, 51 (1961).
}

はいたつていないようである。

外国に和いては，鋳銑鉄の現場分析に実用化している 例として, Motor Casting Co. ${ }^{7)}$ がある.

筆者らは，鋳鉄中のリン分析定湿式化学分析によつて いたが，他の元素に比較して特に長時間を要し，非能率 であるので，作業合理化のため，カントレコーダによる 定量法について研究を試みた。

検討の結果，一応の結論をえたのでここに報告する.

\section{2. 装置}

1. 島津 GQ-220 大形回折格子分光器

凹面曲率半径 $2218 \mathrm{~mm}$

$1 \mathrm{~mm}$ 当り線数 1200 本 $/ \mathrm{mm}$

測定波長範囲 $2100 \AA 200 \AA$ ( 1 次)

分 散 度 $3.8 \AA / \mathrm{mm}$ ( 1 次)

5）真鍋，金原：鉄之鋼，10，1503 (1961).

6) R.E. Michaelis : 1961 Pittsburgh Conference, 198.

7) E.L. Roth, G. Autonic: Foundry, 3, 149 (1961). 
$1.9 \AA / \mathrm{mm}$ (2 次)

分 散 系 Bausch and Lomb 社製凹面 回折格子の Paschen Runge mounting

入ロスリット最小目盛 $0.001 \mathrm{~mm}$ (常時 $50 \mu$ )

出ロスリット Fe $2714 \AA 100 \mu$

$\mathrm{P} 2149 \AA \times 230 \mu$

2. 測光装置 (島津社䜃)

$\begin{array}{lr}\text { Integrators } & 18 \\ \text { Channels } & 47 \\ \text { Channel selectors } & 7\end{array}$

3. 発光装置

島津高性能発光装置

電源 A.C. $200 \mathrm{~V}, 10 \mathrm{~kW}$

4. 分析線対

Fe II 2714. $4 \AA$

P I $2149.1 \AA \times 2$

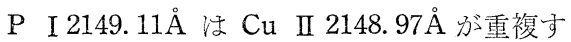
るので，2次を用いて $\mathrm{Cu}$ の影響をスリット で除去した。さらに 2 次に重複する Fe I

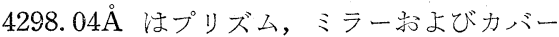
によつて防除した。

5. 附带設備

1) 除震設備

2）定電圧装置（富士電機製15KVA）

3) 恒温恒湿設備

大阪金属社製

温度 $22^{\circ} \mathrm{C} \pm 1{ }^{\circ} \mathrm{C}$ 湿度 $55 \% \pm 5 \%$

コンプレッサー $3 \mathrm{PP} 2$ 台

\section{3. 実験おむび考察}

\section{1. 標準試料}

高周波炉にて溶成した試料学標準試料とした。標準試

Table 1. Chemical compositions of standard samples.

\begin{tabular}{c|c|c|c|c|c|c|c|c|c}
\hline \multirow{2}{\text{Sample}}{\begin{tabular}{c} 
No. \\
\cline { 2 - 5 }
\end{tabular}} & \multicolumn{5}{|c}{ Chemical compositions (\%) } \\
\cline { 2 - 5 } & $\mathrm{P}$ & $\mathrm{C}$ & $\mathrm{S}$ & $\mathrm{Si}$ & $\mathrm{Mn}$ & $\mathrm{Ni}$ & $\mathrm{Cr}$ & $\mathrm{Mo}$ & $\mathrm{Cu}$ \\
\hline
\end{tabular}

\begin{tabular}{l|l|l|l|l|l|l|l|} 
CK-1 & 0.0923 .120 .0101 .400 .931 .631 .820 .190 .41
\end{tabular} CK-2 0.1893 .450 .0051 .230 .671 .851 .570 .220 .27 \begin{tabular}{l|l|l|l|l|l|l|l|l|l|l|l|}
$\mathrm{CK}-3$ & 0.28 & 3.200 .005 & 1.030 .49 & 2.33 & 1.280 .27 & 0.23
\end{tabular} \begin{tabular}{l|l|l|l|l|l|l|l|l|l|l|l|l|}
$\mathrm{CK}-4$ & 0.38 & 3.090 .011 & 0.82 & 0.372 .68 & 1.04 & 0.31 & 0.19
\end{tabular}

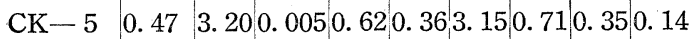
\begin{tabular}{l|l|l|l|l|l|l|l|l|}
$\mathrm{CK}-6$ & 0.54 & 2.900 .0130 .360 .283 .380 .440 .390 .09
\end{tabular} \begin{tabular}{l|l|l|l|l|l|l|l|l|l|l|l|}
$\mathrm{CK}-7$ & 0.64 & 2.85 & 0.014 & 0.28 & 0.15 & 3.98 & 0.350 .430 .05
\end{tabular}
料の一例を Table 1 に示す.

\section{2. 発光条件について}

1） $\mathrm{Fe}$ および $\mathrm{P}$ の測光回路の安定度

Table 2 に示すごとく変動係数は約 $0.3 \%$ にて測光回 路の安定度は良好である。

Table 2. Precision of recording console.

\begin{tabular}{|c|c|c|c|c|}
\hline Spectral lines & $\begin{array}{r}\mathrm{PI} 2149 \\
\times 2 \\
\end{array}$ & $\mid \begin{array}{r}2149 \\
\times 2\end{array}$ & FeII 2714 & FeI 3205 \\
\hline Att. scale & $18-0$ & $18-0$ & $2-0$ & $0-0$ \\
\hline Sense & $\times 1$ & $\times 2$ & 0 & 0 \\
\hline 1 & 41.0 & 48.7 & 30.2 & 39.7 \\
\hline 2 & 41.0 & 48.9 & 30.2 & 39.8 \\
\hline 3 & 41.0 & 49.0 & 30.2 & 39.9 \\
\hline 4 & 41.2 & 48.7 & 30.3 & 39.8 \\
\hline 5 & 41. 0 & 48.9 & 30.2 & 39.8 \\
\hline 6 & 40.8 & 48.8 & 30.2 & 39.8 \\
\hline 7 & 41.2 & 48.8 & 30.2 & 39.9 \\
\hline 8 & 41.0 & 48.5 & 30.2 & 39.8 \\
\hline 9 & 41. 0 & 48.7 & 30.1 & 39.9 \\
\hline 10 & 41.2 & 48.7 & 30.2 & 39.8 \\
\hline 11 & 40.9 & 48.7 & 30.1 & 39.9 \\
\hline $\begin{array}{c}\text { Mean value of } \\
\text { reading }\end{array}$ & 41.0 & 48.8 & 30.2 & 39.8 \\
\hline $\begin{array}{l}\text { Standard } \\
\text { deviation }\end{array}$ & 0.13 & 0.14 & 0.055 & 0.07 \\
\hline $\begin{array}{l}\text { Coefficient of } \\
\text { variation }(\%)\end{array}$ & 0.32 & 0.29 & 0.18 & 0.18 \\
\hline
\end{tabular}

2) 励起条件について

励起条件它決定するために，P含有量 $0.092 \% ， 0.47$ $\% の 2$ 個の試料を用いて回路常数 L, C, Rを種々に組 夕合わせて得られる放電のうち, 若干の励起条件をえら び，それぞれの積分強度（チャートのよみ）学求めた.

発光条件は 1 次電圧約 $190 \mathrm{~V}$, 試料間陌 $2 \mathrm{~mm}$, 予備 放電時間 10 秒, 積分時間 27 秒, 対電極 $6.2 \mathrm{~mm} \phi$ 黑鉛電 極である. 得られた結果は, Table 3 に示す.

Table 3 からタれば明らかに $\mathrm{R}^{2}>4 \mathrm{~L} / \mathrm{C}$ の条件でな ければ分析は不可能である。すなわら， Case 8１4の 励起条件についてくり方えし精度の比較を試夕た結果 を Table 4 亿示す. Case 14 浪もL B 比が大きいも のの 1 つであるが，放電火花のふらつきが非常に顕著で あるため，精度が悪い. Case 11 が他に比較してすぐれ ている.よつて Case 11 を採用することにした. 鋼の 場合も，Case 11 が最もよいという結果が発表されて いる2). 
Table 3. Preliminary experiment for determining excitation conditions.

\begin{tabular}{|c|c|c|c|c|c|c|c|c|}
\hline Case No. & $\mathrm{C}(\mu \mathrm{F})$ & $\mathrm{R}(\Omega)$ & $\mathrm{L}(\mu \mathrm{F})$ & $\mathrm{V}_{f}$ & $\mathrm{~V}_{s}$ & $\begin{array}{c}\text { A. Intensity* } \\
\mathrm{P} 0.092 \%\end{array}$ & $\begin{array}{l}\text { Intensity** } \\
\mathrm{P} 0.47 \%\end{array}$ & $A-B$ \\
\hline 1 & 5 & 10 & 50 & 190 & 840 & 12 & 12.5 & 0.5 \\
\hline 2 & 10 & 1.25 & 50 & 190 & 860 & 16.5 & 18 & 1.5 \\
\hline 3 & 10 & 1.25 & 360 & 190 & 860 & 18 & 24.5 & 6.5 \\
\hline 4 & 10 & 5 & 50 & 190 & 860 & 12.5 & 14 & 1.5 \\
\hline $5 *$ & 10 & 5 & 360 & 190 & 850 & 18 & 21 & 3 \\
\hline $6^{*}$ & 10 & 10 & 360 & 190 & 850 & 16 & 18 & 2 \\
\hline $7^{*}$ & 10 & 30 & 360 & 190 & 850 & 13 & 22 & 9 \\
\hline $8^{*}$ & 20 & 50 & 50 & 192 & 875 & 25 & 69.5 & 44.5 \\
\hline $9 *$ & 20 & 50 & 360 & 192 & 875 & 25 & 67 & 42 \\
\hline 10 & 30 & 50 & 50 & 190 & 900 & 16.5 & 24 & 7.5 \\
\hline $11 *$ & 30 & 50 & 360 & 190 & 910 & 66.5 & 100 & 33.5 \\
\hline $12^{*}$ & 35 & 50 & 360 & 190 & 920 & 68 & 113 & 45 \\
\hline $13 *$ & 50 & 50 & 50 & 192 & 980 & 90 & 153 & 63 \\
\hline 14 & 50 & 50 & 360 & 194 & 990 & 88 & 125 & 37 \\
\hline 15 & \multicolumn{2}{|c|}{ High voltage spark } & $\mathrm{L}=0$ & $=\mathrm{W}$ & $140 \mathrm{~V}$ & 16 & 16.5 & 0.5 \\
\hline
\end{tabular}

* Recorder zero 20 , sense $\times 4$.

** Chart reading.

Table 4. Comparison of excitation conditions for cases 11,12 and 14 of Table 3.

\begin{tabular}{|c|c|c|c|c|c|c|c|c|c|}
\hline \multicolumn{2}{|c|}{ Kind of samples } & \multicolumn{2}{|c|}{$\mathrm{CK}-1$} & \multicolumn{2}{|c|}{$C K-5$} & \multicolumn{2}{|c|}{$\mathrm{CK}-2$} & \multicolumn{2}{|c|}{$\mathrm{CK}-4$} \\
\hline \multicolumn{2}{|c|}{ Phosphorus (\%) } & \multicolumn{2}{|c|}{0.092} & \multicolumn{2}{|c|}{0.47} & \multicolumn{2}{|c|}{0.189} & \multicolumn{2}{|c|}{0.38} \\
\hline \multicolumn{2}{|c|}{ Elements } & $\mathrm{Fe}$ & $\mathrm{P}$ & $\mathrm{Fe}$ & $\mathrm{P}$ & $\mathrm{Fe}$ & $\mathrm{P}$ & $\mathrm{Fe}$ & $\mathrm{P}$ \\
\hline \multicolumn{2}{|c|}{ Att. scale } & $2-0$ & $18-0$ & $2-0$ & $18-0$ & $2-0$ & $18-0$ & $2-0$ & $18-0$ \\
\hline \multirow{3}{*}{ Case 11} & M & 56.3 & 51.6 & 63.0 & 90.6 & 59.8 & 72.7 & 63.5 & 97.9 \\
\hline & $\sigma$ & 2.21 & 1.42 & 2.23 & 2.75 & 2.64 & 1.55 & 4.21 & 3.74 \\
\hline & $\mathrm{V}$ & 3.93 & 2.75 & 3. 54 & 3. 04 & 4. 41 & 2. 14 & 6.63 & 3.82 \\
\hline \multirow{3}{*}{ Case 12} & M & 49.6 & 46.9 & 55.9 & 122.2 & $* 67.4$ & $* 82.0$ & $* 82.5$ & $* 93.6$ \\
\hline & $\sigma$ & 2.81 & 1. 47 & 4.96 & 4.02 & 9.24 & 3.49 & 10.06 & 5.49 \\
\hline & $\mathrm{V}$ & 5.67 & 3. 13 & 8.88 & 3.29 & 13. 70 & 4. 26 & 12.19 & 5.87 \\
\hline \multirow{3}{*}{ Case 14} & M & 86.0 & 75.5 & 112.1 & 150.0 & - & - & - & - \\
\hline & $\sigma$ & 12.92 & 9.87 & 23.12 & 23.91 & - & - & - & - \\
\hline & $\mathrm{V}$ & 15.02 & 13.07 & 20.62 & 15. 94 & - & - & - & - \\
\hline
\end{tabular}

Case 11: C; $30 \mu \mathrm{F}, \mathrm{R} ; 50 \Omega, \mathrm{L} ; 360 \mu \mathrm{H}, \mathrm{V}_{f} ; 170 \mathrm{~V}(1.0 \mathrm{~A})$, Gap; $2 \mathrm{~mm}$, pre-spark time; 10 sec., Integ. time; 25 sec., Couter electrode; Graphite.

Case 12: C; $35 \mu \mathrm{F}, \mathrm{R} ; 50 \Omega, \mathrm{L} ; 360 \mu \mathrm{H}, \mathrm{V}_{f} ; 170 \mathrm{~V}(1.25 \mathrm{~A})$ [*150V (1.1A)], Gap; $2 \mathrm{~mm}[* 1 \mathrm{~mm}$, Pre-spark time; $10 \mathrm{sec} .[* 20 \mathrm{sec}$.$] , Integ. time; 25 \mathrm{sec}$., Counter electrode; Graphite.

Case 14: $\mathrm{C} ; 50 \mu \mathrm{F}, \mathrm{R} ; 50 \Omega, \mathrm{L} ; 360 \mu \mathrm{H}, \mathrm{V}_{f} ; 170 \mathrm{~V}(1.75 \mathrm{~A})$, Gap; $2 \mathrm{~mm}$, Pre-spark time; 10 sec., Integ. time; 25 sec., Counter electrode; Graphite.

M: Mean value of reading ( $\mathrm{n}: 11)$. $\sigma$ : Standard deviation. V: Coefficient of variation (\%). 
3）予備放電時間について

予備放電時間を決定するために, 各励起条件にてPの スペクトルの瞬間強度を profile して, その瞬間強度の 時間的变化を求めた．それぞれ，8〜20秒にてやや安定 するごとく思われるが明確な判断がつかないので, Case 11 の励起条件にて予備放電時間 10 秒々 20 秒の比較実験 を行なつた. その結果を Table 5 に示した。

Table 5 の結果によると, 定時間積分法による予備放 電時間10秒が最もよい.

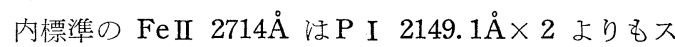
ペクトル強度が不安定である.よつて内標準を使用する よりも定時間積分方式の方がすぐれた結果をうることが できる.

4) 試料間陌について

試料間隙通常 $2 \mathrm{~mm}$ を使用している.こころみに 1 $\mathrm{mm}$ 使用して比較を行なつた。 その結果は, Table 5 に示したごとく大差はないが， $2 \mathrm{~mm}$ 方がやや優れて いるように思わ秃る. 日常は $2 \mathrm{~mm}$ 分析を行なつて いるので作業上からも $2 \mathrm{~mm}$ mが都合がよい。

5) 一次電圧について
一次電圧の影響について検討を行なつた. Table 6 に 示したごとく, $150 \mathrm{~V}, 170 \mathrm{~V}, 190 \mathrm{~V}$ の電圧では精度に影 響惊よぼさない. ややよい結果を表わした $170 \mathrm{~V}$ に一 次電圧を決定した。

6) その他

対電極注黑鉛の外に銀を使用して検討したが，両者の 優劣は認められなかつた，経済上小よび取り扱い上から 黑鉛が有利であるので，黑鉛を使用することにした.

以上より発光条件として次の条件を確立した.

一次電圧 $170 \mathrm{~V}$

静電容量 $(\mathrm{C}) \quad 30 \mu \mathrm{F}$

抵 抗(R) $50 \Omega$

自己誘導 $(\mathrm{L}) \quad 360 \mu \mathrm{H}$

試料間陌 $2 \mathrm{~mm}$

対 電 極 黒鉛 $6.2 \mathrm{~mm} \phi$ 尖端 $120^{\circ}$ 円錐形

予備放電時間 10 秒

積 分 時間 20 秒一定時間積分方式

(Fe 内標準は使用せず)

試 料 極 性 $(+)$ 極

Table 5. Test of pre-spark time.

\begin{tabular}{|c|c|c|c|c|c|c|}
\hline \multirow{2}{*}{\multicolumn{2}{|c|}{\begin{tabular}{|c|c|c|} 
& Kind of samples \\
Conditions & Elements \\
\end{tabular}}} & \multicolumn{2}{|c|}{$\mathrm{CK}-1$} & \multicolumn{2}{|c|}{$\mathrm{CK}-5$} & \multirow{2}{*}{ Notes } \\
\hline & & $\mathrm{Fe}$ & $\mathrm{P}$ & $\mathrm{Fe}$ & $\mathrm{P}$ & \\
\hline $\begin{array}{c}\text { Fe } 2-0, \text { P } 18-0 \\
\text { Gap: } 1 \mathrm{~mm}, \\
\text { Pre-spark time: } 10 \text { sec. }\end{array}$ & $\begin{array}{l}\mathrm{M} \\
\sigma \\
\mathrm{V}\end{array}$ & $\begin{array}{r}79.0 \\
6.7 \\
8.5\end{array}$ & $\begin{array}{l}23.5 \\
1.34 \\
5.7\end{array}$ & $\begin{array}{c}97.0 \\
2.89 \\
3.0\end{array}$ & $\begin{array}{l}61.0 \\
4.68 \\
7.7\end{array}$ & $\begin{array}{l}\text { Constant time } \\
\text { integration }\end{array}$ \\
\hline $\begin{array}{c}\text { Fe } 1-0, \text { P } 18-0, \\
\text { Gap : } 2 \mathrm{~mm}, \\
\text { Pre-spark time: } 10 \mathrm{sec} .\end{array}$ & $\begin{array}{l}\mathrm{M} \\
\sigma \\
\mathrm{V}\end{array}$ & $\begin{array}{r}76.5 \\
8.0 \\
10.5\end{array}$ & $\begin{array}{r}27.5 \\
0.8 \\
2.9\end{array}$ & $\begin{array}{r}74.5 \\
5.4 \\
7.3\end{array}$ & $\begin{array}{r}66.0 \\
2.9 \\
4.4\end{array}$ & $\begin{array}{c}\text { Constant time } \\
\text { integration }\end{array}$ \\
\hline $\begin{array}{c}\text { Fe } 1-0, \text { P } 18-0, \\
\text { Gap: } 2 \mathrm{~mm}, \\
\text { Pre-spark time: } 20 \mathrm{sec} .\end{array}$ & $\begin{array}{l}\mathrm{M} \\
\sigma \\
\mathrm{V}\end{array}$ & $\begin{array}{l}69.5 \\
2.75 \\
4.0\end{array}$ & $\begin{array}{c}37.0 \\
1.22 \\
3.3\end{array}$ & $\begin{array}{l}70.5 \\
12.5 \\
17.7\end{array}$ & $\begin{array}{l}59.5 \\
3.98 \\
6.7\end{array}$ & $\begin{array}{c}\text { Constant time } \\
\text { integration }\end{array}$ \\
\hline $\begin{array}{c}\text { Fe 2-0, P } 18-0, \\
\text { Gap: } 1 \mathrm{~mm}, \\
\text { Pre-spark time: } 20 \mathrm{sec} .\end{array}$ & $\begin{array}{l}\mathrm{M} \\
\sigma \\
\mathrm{V}\end{array}$ & $\begin{array}{r}91.5 \\
7.7 \\
8.4\end{array}$ & $\begin{array}{l}76.0 \\
0.81 \\
1.1\end{array}$ & $\begin{array}{r}119.0 \\
4.7 \\
4.0\end{array}$ & $\begin{array}{r}107.0 \\
6.2 \\
5.8\end{array}$ & $\begin{array}{c}\text { Constant time } \\
\text { integration } \\
\text { Recorder sence } \times 2\end{array}$ \\
\hline $\begin{array}{c}\text { Fe } 2-0, \text { P } 18-0, \\
\text { Gap: } 2 \mathrm{~mm}, \\
\text { pre-spark time: } 20 \mathrm{sec} .\end{array}$ & $\begin{array}{l}\mathrm{M} \\
\sigma \\
\mathrm{V}\end{array}$ & & & & & $\begin{array}{l}\text { Internal standard } \\
\text { method } \\
(\text { FeI } 2715 \AA)\end{array}$ \\
\hline $\begin{array}{c}\text { Fe } 2-0, \text { P } 18-0, \\
\text { Gap: } 2 \mathrm{~mm}, \\
\text { pre-spark time: } 10 \mathrm{sec} .\end{array}$ & $\begin{array}{l}\mathrm{M} \\
\sigma \\
\mathrm{V}\end{array}$ & & & & $\begin{array}{l}0 \\
78 \\
6\end{array}$ & $\begin{array}{c}\text { Internal standard } \\
\text { method } \\
(\mathrm{FeI} 2715 \AA)\end{array}$ \\
\hline
\end{tabular}

Excitation conditions: C; $30 \mu \mathrm{F}, \mathrm{R} ; 50 \Omega, \mathrm{L} ; 360 \mu \mathrm{H}$, Vs; $910 \mathrm{~V}$, Integration time; 27 sec., $\mathrm{n}: 5$. 
Table 6. Test of power circuit.

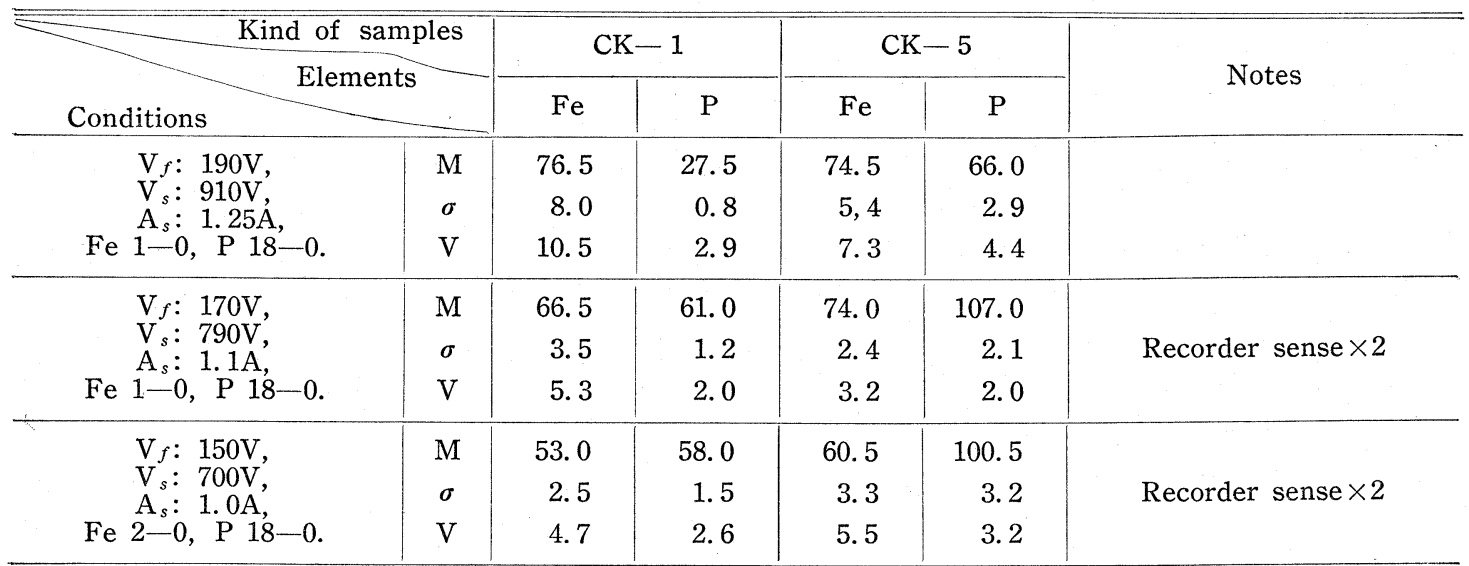

Excitation conditions: C; $30 \mu \mathrm{F}, \mathrm{R} ; 50 \Omega, \mathrm{L} ; 360 \mu \mathrm{H}$, Gap; 2mm, Pre-spark time; 10sec., Constant time integration; 27sec., Counter electrode; Graphite.

$M$ : Mean value of chart reading $(n ; 5)$.

$\sigma:$ Standard deviation.

$\mathrm{V}$ : Coefficient of variation (\%).

Table 7. Effect of grinding of samples.

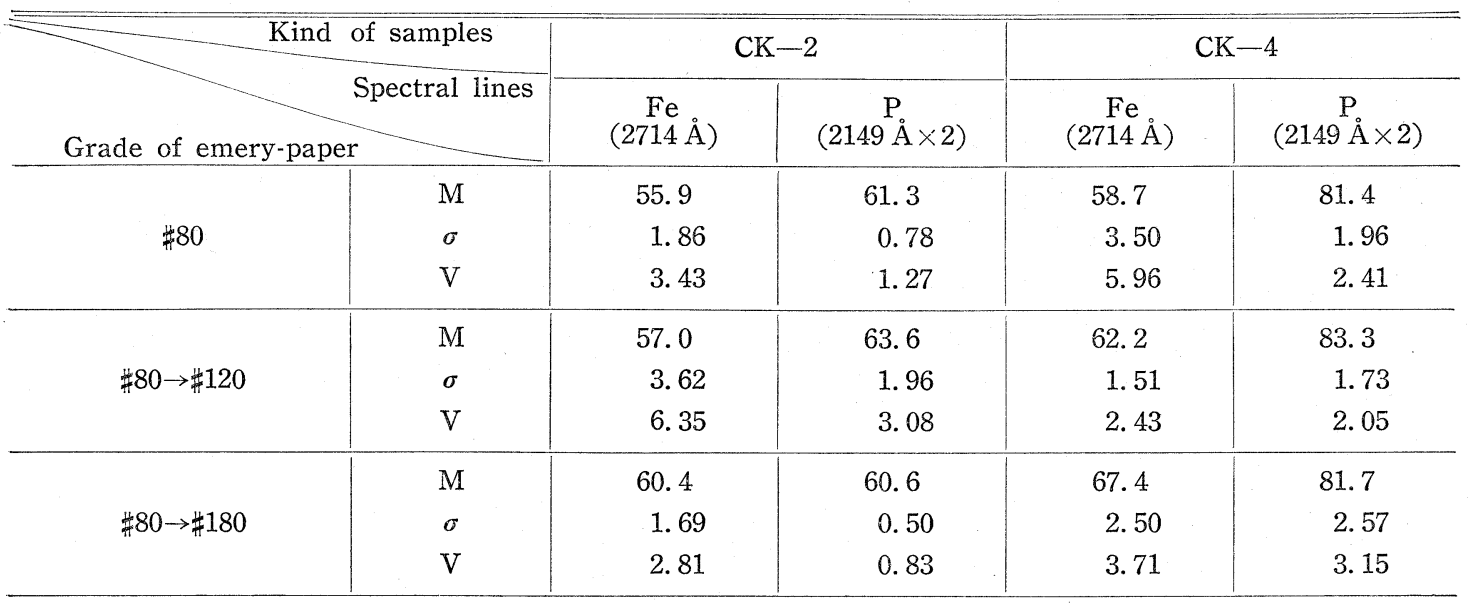

Excitation conditions: C; $30 \mu \mathrm{F}, \mathrm{R} ; 50 \Omega, \mathrm{L} ; 360 \mu \mathrm{H}$, Gap; 2mm, Pre-spark time; 10sec., Constant time integration; 27sec., Counter electrode; Graphite.

$\mathrm{M}$ : Mean value of chart reading ( $\mathrm{n}: 5$ ).

$\sigma$ : Standard deviation.

$\mathrm{V}$ : Coefficient of variation (\%).

\section{3. 試料の調製}

試料調製の検討は，グラインダーにて粗仕上げし，電 気ベルタにて研磨布の粒度 $\$ 80, \$ 80 \rightarrow \# 120, \# 80 \rightarrow \$ 180$ で仕上げてそれぞれを比較した。検討結果をTable 7 に示した. Table 7 にると, それぞれの精度の優劣は 判別し難かつた.
つぎに，研磨の仕上程度の検討を行なつた。すなわち \#80 $\rightarrow$ \#120 にて仕上げをなし, その研磨面が日常作業よ りやや悪く研磨された試料と, 極めて丁寧に研磨し, 微 細クラックを見わけて良部のタを放電しうるようにした 試料との比較を行なつた結果を, Table 8 に示した. 
これによると, 極めて丁寧に研磨し微細クラックを見 わけて良部のみを放電すれば優秀な結果が得られること がわかる. 試料面の良い部分とクラックおよび研磨不良 の部分とを放電し，その比較を行なつた結果は，Table 9 に示した.

これによつても研磨不良, クラック等が誤差の原因と なることがわかる、また，クラック部沅研磨不良部より 誤差が大きい，結局，研磨布の粒度が分析に適合するこ とが必要であるが，研磨面を丁寧に一定でかつ一様に仕 上げると共に微細クラック等を避けて放電することが精 度を維持するために必要である。

異状部分を発見するためには，できるだけ細い粒度の 研磨布を使用する方が有利である.

日常作業として試料の調製は，グラインダーにて粗仕 上げをし，電気ベルタにて粒度 \#80で中仕上げ後極めて 丁寧に粒度 \#120 で一定でかつ一様に仕上げをすること
に決定した。

Table 8. Effect of polishing of samples.

\begin{tabular}{c|c|c|c|c}
\hline \hline \multicolumn{2}{c|}{ Kind of samples } & CK-1 & CK-3 & CK-5 \\
Conditions & $\mathrm{M}$ & 50.8 & 73.0 & 86.2 \\
Unsuitable & $\sigma$ & 1.28 & 3.58 & 5.54 \\
polishing & $\mathrm{V}$ & 2.52 & 4.90 & 6.43 \\
\hline \multirow{2}{*}{ Suitable } & $\mathrm{M}$ & 52.3 & 78.1 & 94.2 \\
polishing & $\sigma$ & 1.22 & 1.91 & 1.80 \\
& $\mathrm{~V}$ & 2.33 & 2.45 & 1.91 \\
\hline
\end{tabular}

Excitation conditions: same as above (Table 7.)

Polishing: grinder $(\sharp 60) \rightarrow \sharp 80 \rightarrow \sharp 120$.

$\mathrm{M}$ : Mean value of chart reading ( $\mathrm{n}: 5$ ).

$\sigma:$ Standard deviation.

$\mathrm{V}$ : Coefficient of variation $(\%)$.

Table 9. Analytical results for $\mathrm{P}$ with various conditions of sample surface.

\begin{tabular}{|c|c|c|c|c|}
\hline \multirow{2}{*}{ Sample No. } & \multirow{2}{*}{$\begin{array}{c}\text { Chemical result } \\
P(\%)\end{array}$} & \multicolumn{3}{|c|}{ Surface conditions } \\
\hline & & $\begin{array}{l}\text { Suitable part } \\
\mathrm{P}(\%)\end{array}$ & $\begin{array}{c}\text { Crack part } \\
\mathrm{P}(\%)\end{array}$ & $\begin{array}{c}\text { Unsuitable part } \\
\mathrm{P}(\%)\end{array}$ \\
\hline 1 & 0.37 & 0.37 & $0.38,0.42$ & - \\
\hline 2 & 0.21 & 0.21 & 0.23 & - \\
\hline 3 & 0.22 & 0.23 & 0.26 & - \\
\hline 4 & 0.34 & 0.34 & $0.34,0.37$ & - \\
\hline 5 & 0.36 & 0.37 & $0.41,0.47$ & - \\
\hline 6 & 0.43 & 0.42 & 0.45 & - \\
\hline 7 & 0.44 & 0.44 & \multicolumn{2}{|c|}{$0.36 \sim 0.40$} \\
\hline 8 & 0.33 & 0.33 & \multicolumn{2}{|c|}{$0.29 \sim 0.34$} \\
\hline 9 & 0.43 & 0.42 & \multicolumn{2}{|c|}{$0.38 \sim 0.45$} \\
\hline 10 & 0.39 & 0.38 & - & 0.39 \\
\hline 11 & 0.13 & 0.14 & 0.15 & - \\
\hline 12 & 0.18 & 0.18 & 0.20 & - \\
\hline 13 & 0.22 & 0.21 & \multicolumn{2}{|c|}{$0.22 \sim 0.24$} \\
\hline 14 & 0.20 & 0.19 & \multicolumn{2}{|c|}{$0.17 \sim 0.19$} \\
\hline 15 & 0.18 & 0.19 & \multicolumn{2}{|c|}{$0.19 \sim 0.20$} \\
\hline
\end{tabular}

\section{4. 試料の熱履歴および共存元素の影響}

試料の分析面のミクロ組織は採取時および調製時の熱 履歴によつて変化する. また含有する成分の量によつて もことなる，そこで，使用する標準試料と被検試料との 間にてミク口組織等が相違すると，分析值の正確度に影 響する，日常作業として，試料の採取およよび調製は一 定の条件にて行ない，熱履歴および含有量の類似した標 準試料によつてえた検量線にて被倹試料を測定してい
る ${ }^{8) 9)}$.

白鋳鉄中のリンについても熱履歴の影響があることが 予想できるので検討を行なつた. 金形にて鋳造し，ただ ちに水冷却した試料（帅前迅速分析用）と鋳造後放冷し $550^{\circ} \mathrm{C} \times 2 \mathrm{~h}$. にて焼鈍した試料（鍋下試料）によりえ た検量線を比較した. その結果を Fig. 1 亿示す.

8）岡, 根本, 倉田: 分光研究, 4, 201 (1961).

9）岡, 根本, 倉田: 学振垁告19委-6054 (1960). 
それぞれの検量線はやや差異があり，焼針試料による 検量線は, 水冷試料の検量線より下部になり, スペクト ル強度は弱い。

共存元素の影響は, Table 1 に示した程度の含有量に ては認められなかつた。

銅の影響は，鋼の場合と同様に $0.4 \%$ までは認められ なかつた1).

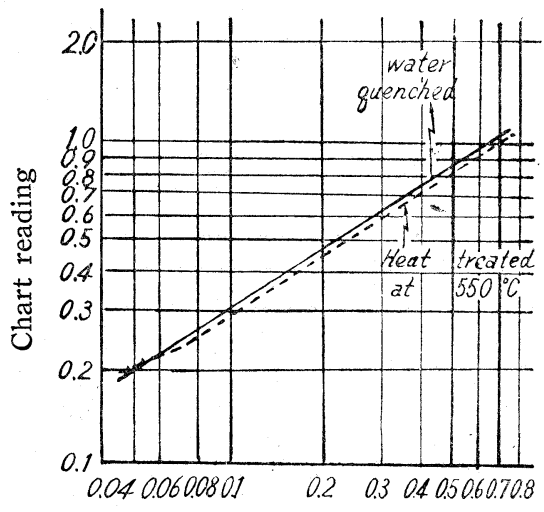

Phosphorus (\%)

Fig. 1. Comparison of analytical results for $\mathrm{P}$ with annealed samples and water quenched samples.
炭素の影響は，Table 10. に示すどとく，2.5〜3.8\% にては影響は認められない。

\section{5. 精 度}

上述の発光条件によつて,精度を検討した結果の例を， Table 11 に示した. この結果によると, 変動係数は, $2 \sim 4 \%$ \%炉前迅速分析に性用できることが判る. なお，試料の分析面に注意して定量すれば精度はさらに よくなり，変動係数は $3 \%$ 以下になる。

Table 10. Effect of carbon contents.

\begin{tabular}{c|c|c|c}
\hline $\begin{array}{c}\text { Sample } \\
\text { No. }\end{array}$ & $\begin{array}{c}\text { Carbon cont- } \\
\text { ents (\%) }\end{array}$ & $\begin{array}{c}\text { Chemical resu- } \\
\text { its of P (\%) }\end{array}$ & $\begin{array}{c}\text { Quantometric re- } \\
\text { sults of P (\%) }\end{array}$ \\
\hline 1 & 3.76 & 0.33 & 0.335 \\
2 & 3.56 & 0.32 & 0.33 \\
3 & 3.42 & 0.32 & 0.225 \\
4 & 3.36 & 0.32 & 0.32 \\
5 & 3.24 & 0.32 & 0.33 \\
6 & 2.93 & 0.35 & 0.36 \\
7 & 2.86 & 0.35 & 0.37 \\
8 & 2.80 & 0.35 & 0.355 \\
9 & 2.68 & 0.35 & 0.36 \\
10 & 2.58 & 0.35 & 0.35 \\
\hline
\end{tabular}

Table 11. Precision of analysis.

\begin{tabular}{c|c|c|c|c}
\hline Kind of samples & CK-2 & CK-4 & F 1075 & 10891 \\
\hline Express & 70 & 97 & 89.5 & 73.5 \\
2 & 73 & 97 & 90.5 & 76 \\
3 & 72 & 101.5 & 90.5 & 76 \\
4 & 74 & 94 & 92.5 & 76 \\
5 & 74.5 & 93.5 & 92 & 81.5 \\
6 & 72 & 100 & 95.5 & 75 \\
7 & 74 & 98 & 94 & 77.5 \\
8 & 71 & 93.5 & 91.5 & 79.5 \\
9 & 73 & 96 & 87.5 & 74 \\
\hline 11 & 74 & 101.5 & 94.5 & 76.8 \\
\hline M & 72.5 & 101 & 91.8 & 2.35 \\
\hline$\sigma$ & 72.7 & 97.9 & 2.32 & 3.06 \\
\hline Range & 1.42 & 3.74 & 2.52 & $73.5 \sim 81$ \\
\hline
\end{tabular}

M: Mean value of chart reading ( $\mathrm{n}: 11)$.

$\sigma:$ Standard deviation.

$\mathrm{V}$ : Coefficient of variation (\%). 


\section{6. 検量線}

Fig. 2 に検量線の一例を示す.

定量適用範囲は，0.04〜0.6\% であるが，0.08\% 以下 にて検量線はやや屈折する傾向がある.

Fig. 1, Fig. 2 の検量線は，発光条件は同一であるに もかかわらず時差によつて平行移動をしている. 分光器 内の温度変化による原因，また怯作業中におこるところ の電圧差異, レコーダ部の zero 調節, sense 調節の差 異等の原因により検量線注動することが判る.

約30分にて検量線が相当のずれを生じた経験がある。 検量線は分析時直前に作成することがのぞましい。

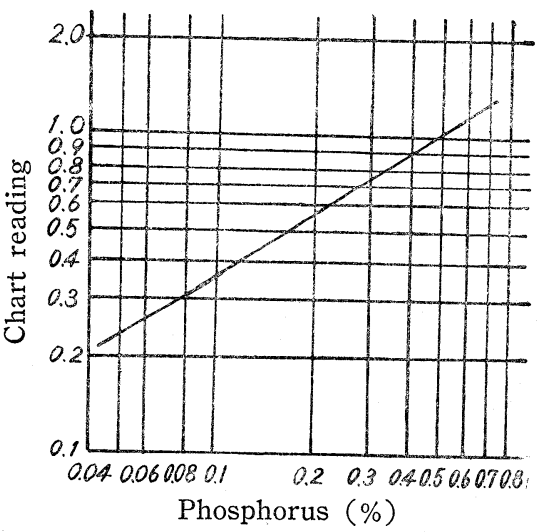

Fig. 2. Working curves for phosphorus in white cast iron.

\section{7. 実際試料における正磪度について}

実際試料によつて，化学分析值と比較検討した結果 を, Table 12 に示した. (Fig. 3 参照)

分析值の差は，-0.02 0. 025\% にて炉前迅速分析と しては許容誤差範囲内である。偏差率の平均は， $2.20 \%$ である.

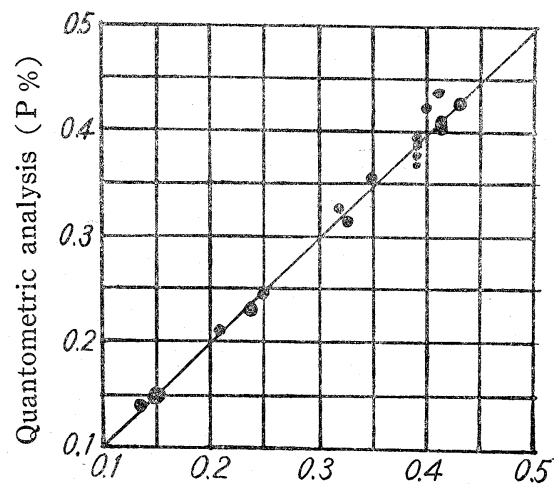

Chemical analysis ( $\mathrm{P} \%)$

Fig. 3. Comparison with chemical analysis and quantometric analysis.
Table 12. Comparison with chemical analysis and quantometric analysis.

\begin{tabular}{c|c|c|c}
\hline $\begin{array}{c}\text { Sample } \\
\text { No. }\end{array}$ & $\begin{array}{c}\text { Chemical resu- } \\
\text { lts }\end{array}$ (\%) & $\begin{array}{c}\text { Quantometric } \\
\text { results (\%) }\end{array}$ & Difference \\
\hline 1 & 0.25 & 0.245 & -0.005 \\
2 & 0.39 & 0.39 & 0 \\
3 & 0.39 & 0.395 & 0.005 \\
4 & 0.41 & 0.405 & -0.005 \\
5 & 0.41 & 0.435 & 0.025 \\
6 & 0.44 & 0.41 & 0 \\
7 & 0.21 & 0.21 & 0 \\
8 & 0.24 & 0.23 & -0.01 \\
9 & 0.33 & 0.315 & -0.015 \\
10 & 0.32 & 0.33 & 0.01 \\
11 & 0.15 & 0.15 & 0 \\
12 & 0.40 & 0.42 & 0.02 \\
13 & 0.35 & 0.355 & 0.005 \\
14 & 0.39 & 0.37 & -0.02 \\
15 & 0.39 & 0.38 & -0.01 \\
16 & 0.14 & 0.14 & 0 \\
17 & 0.43 & 0.43 & 0 \\
\hline
\end{tabular}

Range of difference: $-0.02 \sim 0.025$.

Mean of deviation rate: $2.20 \%$.

\section{5. 結言}

1）カントレコーダにより，白鋳鉄中のリン定量を検 討し，炉前迅速法に適用できることを確認した。

2） $0.04 \sim 0.6 \%$ の含有量範囲において，下記の条件 のもとに炉前迅速分析用として十分使用できる. 变動係 数は, $2 \sim 4 \%$, 分析所要時間は, 約 5 分である.

3）発光条件は，

$\mathrm{C} ; 30 \mu \mathrm{F}, \mathrm{R} ; 50 \Omega, \mathrm{L} ; 360 \mu \mathrm{H}$, 一次電圧; $170 \mathrm{~V}$, 試料間隙； $2 \mathrm{~mm}$ ，定時間積分方式積分時間； 20 秒, 試料極性; (十) 極, 予備放電時間; 10 秒.

4）試料採取は，他の元素の分析試料の場合と同様に できるだけ同一条件にて採取し，分析面のミク口組織を 一定かつ一様にすれば，正確度は高められる。

測定は，被検試料と同㥞のミク口組織でかつ，リン以 外の元素の含有量の類似した標準試料によりつくられた 検量線を使用することがのぞましい.

5）分析面の調製は，丁寧に一様かつ一定になるるう に注意して行なわ称ばならない。白鋳鉄試料は，クラッ クが出やすいので, 放電する際は, クラックの部分を避 けて行なうことが定量の要点の一つである.

6) 分光器内の温度変化によつておこる出ロスリット とスペクトル線の位置的関係による影響が特に大きい. 